\section{SOI: 1.1/TAS DOI: 10.15863/TAS International Scientific Journal Theoretical \& Applied Science}

p-ISSN: 2308-4944 (print)

e-ISSN: 2409-0085 (online)

Year: 2017

Issue: 04

Volume: 48

\section{http://T-Science.org}

Ganiyu Adedayo Ajenikoko

Department of Electronic \& Electrical Engineering, Ladoke Akintola University of Technology, P.M.B. 4000, Ogbomoso, Nigeria ajeedollar@gmail.com

Williams Olagoke Agboibon Department of Electronic \& Electrical Engineering, Ladoke Akintola University of Technology, P.M.B. 4000, Ogbomoso, Nigeria

SECTION 6. Metallurgy and energy.

\title{
THE RISKS AND CHALLENGES AFFECTING THE IMPLEMENTATION OF NUCLEAR ENERGY FOR ELECTRICAL POWER GENERATION IN NIGERIA
}

\begin{abstract}
Nigeria as a country has a national power grid with an installed capacity of about 7000MW (Megawatts) of which about 4000MW is obtainable. This paper takes into consideration a method of power generation which apart from being a viable alternative for long-term energy production can also be operated with low costs. The process of large scale industrialization for any nation is fueled by its power sector. The latter is directly proportional to the former, thus meaning that any problems encountered in the power sector are transferred to the industrial sector of such a country. For a country with a population of about 180 million people, over 50000MW is needed to satisfy the industrial and domestic needs of the populace. With the operation of its three Hydro-Electric power stations and seven thermal power stations, all operating at a peak of about 5000MW (as recorded by the Transmission Company of Nigeria in the month of February 2016), it is necessary that other methods of electricity generation that are environmentally friendly and economically competitive be proposed and that the risks and challenges of the implementation of such methods be assessed in order to be able to facilitate the selection of a method of generation that can implemented in order to fast-track the industrial evolution and to revitalize the Nigerian economy. The power outlines the challenges that will be posed and faced by the Nigerian nuclear program which has been activated by the Nigerian Atomic Energy Commission.

Key words: Nuclear Power Plants, Nuclear Reactors, Electricity Generation, Nigerian Atomic Energy Commission, Environmental Impact, Nigerian Power Grid, Nigerian Nuclear Power Program.

Language: English

Citation: Ajenikoko GA, Agboibon WO (2017) THE RISKS AND CHALLENGES AFFECTING THE IMPLEMENTATION OF NUCLEAR ENERGY FOR ELECTRICAL POWER GENERATION IN NIGERIA. ISJ Theoretical \& Applied Science, 04 (48): 49-56.
\end{abstract}

Soi: http://s-o-i.org/1.1/TAS-04-48-8 Doi: crossef https://dx.doi.org/10.15863/TAS.2017.04.48.8

\section{Introduction}

Electricity is a necessity of life. A quarter of the entire world population currently live without electricity with about $95 \%$ of this group of people living in developing countries such as Nigeria. In an age where both industry and the economy are driven by electronic devices, access to electrical power is considered as a basic requirement to economic growth. With a population of about 180 million which makes it the seventh most populous in the world and an economy being regarded as the second largest in Africa, it is appalling to note that only about $40 \%$ of this number have access to electricity, with this privileged $40 \%$ having only epileptic power supply. With an installed grid capacity of $7000 \mathrm{MW}$, less than $4000 \mathrm{MW}$ of electricity is generated presently, which is even lower than what India generates from nuclear power plants alone [IAEA, 2009a; Yusuf 2016]. It is important to note this that total power generated currently is not even enough to satisfy the electrical needs of Lagos state which doubles as the economic center and the most populous state. This lack of adequate power supply has forced Nigerians to resort to the use of electricity generators which burn fossil fuels thus increasing the country's carbon footprint. With the drastic reduction in the price of crude oil worldwide, which is Nigeria's main source of revenue, more companies have closed up shop in Nigeria and moved to other African countries that have a steady power supply, while some are operating at less than optimal capacity. An example is the telecommunications 


\begin{tabular}{|c|c|c|c|c|c|c|}
\hline Impact Factor: & $\begin{array}{l}\text { ISRA (India) } \\
\text { ISI (Dubai, UAF } \\
\text { GIF (Australia) } \\
\text { JIF }\end{array}$ & $\begin{array}{l}=1.344 \\
=0.829 \\
=0.564 \\
=1.500\end{array}$ & $\begin{array}{l}\text { SIS (USA) } \\
\text { PИНЦ (Russia) } \\
\text { ESJI (KZ) } \\
\text { SJIF (Morocco) }\end{array}$ & $\begin{array}{l}=0.912 \\
=0.234 \\
=3.860 \\
=\mathbf{2 . 0 3 1}\end{array}$ & $\begin{array}{l}\text { ICV (Poland) } \\
\text { PIF (India) } \\
\text { IBI (India) }\end{array}$ & $\begin{array}{l}=6.630 \\
=1.940 \\
=4.260\end{array}$ \\
\hline
\end{tabular}

sector, where the intercontinental submarine cables that were laid for optimal data transfer are being underutilized due to operational costs of providing power to the transmission stations nationwide (Esogbue and Osaisai 2011).The problem of providing such a large amount of power as needed for the country is one that can be solved by the use of nuclear power. Nuclear reactors are one of the few alternative sources of electrical power that can be said to be long lasting, environmentally friendly and economically viable. With the advantage of being able to generate over $6000 \mathrm{MW}$ of electrical energy in one plant alone, nuclear power is the immediate solution to the power problem in Nigeria (Francis
2014). This necessity to develop nuclear power in Nigeria is what led to the creation of the Nigerian Atomic Energy Commission (NAEC) in August, 1976 and the launching of the Nigerian nuclear program. NAEC was dormant for thirty years until 2006 when it was activated by the same Head of State that had originally created it 30 years earlier (Emma 2011). NAEC's board was formally inaugurated in July 2006. It is a 10-man board with the President as its head [Osaisai 2011a; Osaisai 2011b]. Nuclear power only accounts for about $11 \%$ of the total world electricity generation even though, it being used to generate power for over fifty years as shown in Figure 1.

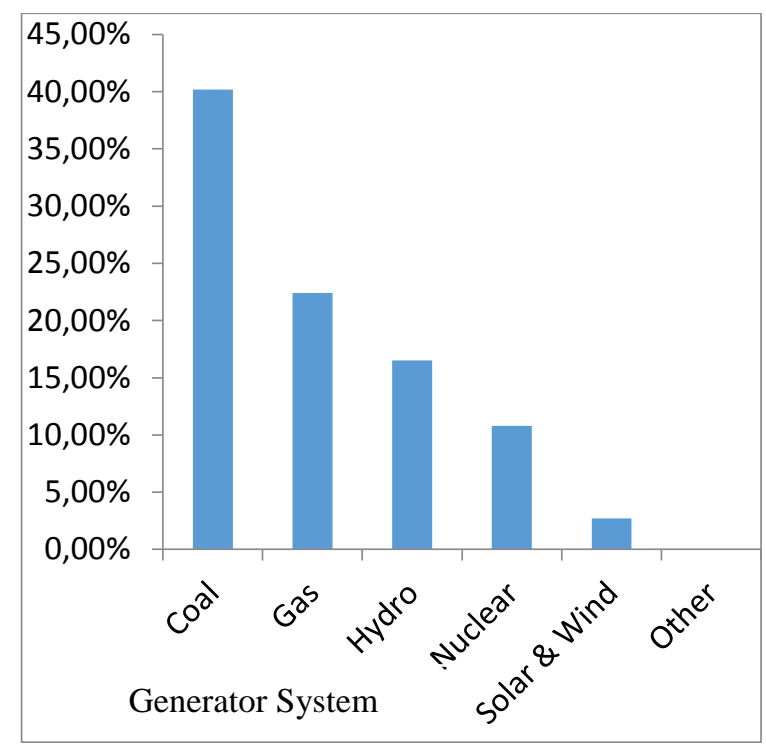

Figure 1 - World Electricity Production.

There are other safer and cleaner options like wind and solar, nuclear technology is still at a stage which makes the later option less practical on a large scale, especially in a developing country. Nuclear reactors can provide safe base-load power on a large scale while taking the dependence away from oil and gas. It also does not have the intermittency problem that plagues most of the frontline renewable energy technologies (NAEC 2011).

\subsection{Nuclear Power}

Nuclear power is the use of nuclear reactors that release nuclear energy to generate heart, which most frequently is then used in stream turbines to produce electricity in nuclear power plant. The term includes nuclear fission, nuclear decay and nuclear fusion. Presently, the nuclear fission of elements in the actinide series of the periodic table produces the vast majority of the nuclear energy in the direct service of humankind. Nuclear power stations use a fuel called uranium, a relatively common material. Energy is released from uranium when an atom is split by the neutron. The uranium atom is split into two and as this happens, energy is released in the form of radiation and heat. This nuclear reaction is called the fission process. In the nuclear power station, the uranium is first form into pallets and then into long rods. The uranium rods are kept cool by submerging then in water. When they are removed from the water, a nuclear reaction takes place causing heat. The amount of heat required is controlled by raising and lowering the rods. If more heat is required, the rods raised further out of the water and if less is needed, they lower further into it.

\subsection{Application of Nuclear Power}

$\square \quad$ The amount of electricity produced in a nuclear power station is equivalent to that produced by a fossil fuelled power station.

$\square \quad$ Nuclear power stations do not burn fossil fuels to produce damaging, polluting gases.

$\square \quad$ Many supporters of nuclear power production say that this type of power is environmentally friendly and clean. In a world that faces global 


\begin{tabular}{|c|c|c|c|c|c|c|}
\hline Impact Factor: & $\begin{array}{l}\text { ISRA (India) } \\
\text { ISI (Dubai, UAF } \\
\text { GIF (Australia) } \\
\text { JIF }\end{array}$ & $\begin{array}{l}=1.344 \\
=0.829 \\
=0.564 \\
=1.500\end{array}$ & $\begin{array}{l}\text { SIS (USA) } \\
\text { PИНЦ (Russia) } \\
\text { ESJI (KZ) } \\
\text { SJIF (Morocco) }\end{array}$ & $\begin{array}{l}=0.912 \\
=0.234 \\
=3.860 \\
=\mathbf{2 . 0 3 1}\end{array}$ & $\begin{array}{l}\text { ICV (Poland) } \\
\text { PIF (India) } \\
\text { IBI (India) }\end{array}$ & $\begin{array}{l}=6.630 \\
=1.940 \\
=4.260\end{array}$ \\
\hline
\end{tabular}

warming, they suggest that increasing the use of nuclear power is the only way of protecting the environment and preventing catastrophic climate change.

$\square \quad$ Many developed countries such as the USA and the UK no longer want to rely on oil and gas imported from the Middle East, a politically unstable part of the world.

\section{Nigerian Nuclear Roadmap}

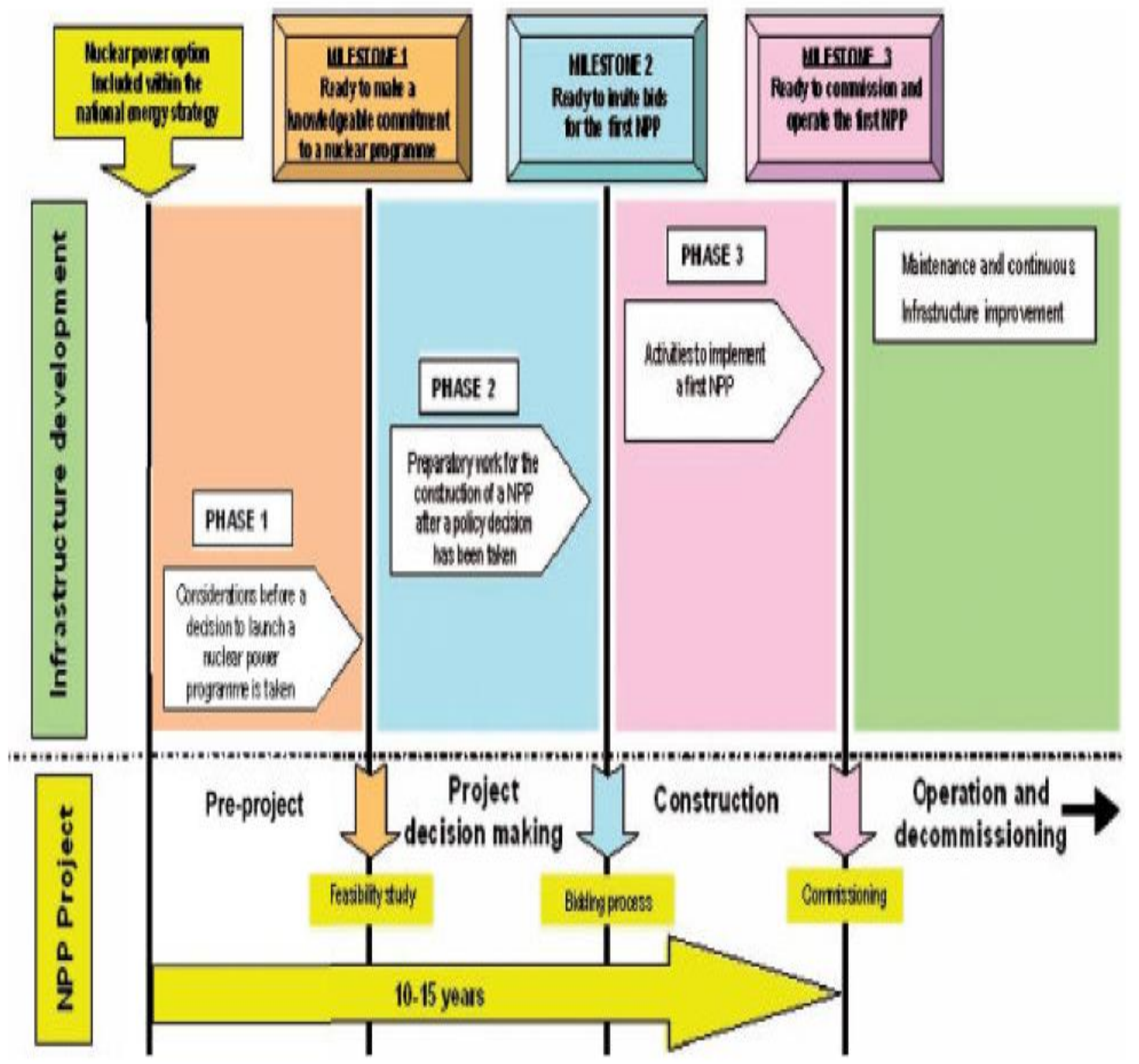

Figure2 - The Three Phases in the Development of a Nuclear Power Programme.

The capacity is to be increased to $4,800 \mathrm{MW}$ by 2035The three phases are (Simon 2015; Yehuwdab 2013):

1. Manpower and infrastructure development

2. Design certification, siting, regulatory and licensing approvals

3. Construction and start up.

The gestation period for the implementation of a nuclear power programme is at least 10 years. An
Since provisions have been made in the National Energy Policy [NAEC, 2011] to treat nuclear power as a viable means of electricity generation, steps have since been taken by the NAEC with a roadmap developed in its first year of operation. The nuclear road map is a three-phase technical frame work which involves the generation of 1, 200 Megawatts of electricity using nuclear power plant by 2025 .

ISPC Industry and technology,

example is Iran where their first nuclear power plant was finally connected to the grid on September 4, 2011 and a ceremony to mark its commissioning was held on the 12th of September 2011. Meanwhile, work began on this plant since 1975 [Yusuf, 2016]. While it takes approximately 10 to 15 years to implement the infrastructural base [IAEA, 2009b], the Nigerian government has proposed 10 to 12 years to have on-line electricity generation from nuclear. 


\begin{tabular}{|c|c|c|c|c|c|c|}
\hline Impact Factor: & $\begin{array}{l}\text { ISRA (India) } \\
\text { ISI (Dubai, UAF } \\
\text { GIF (Australia) } \\
\text { JIF }\end{array}$ & $\begin{array}{l}=1.344 \\
=0.829 \\
=0.564 \\
=1.500\end{array}$ & $\begin{array}{l}\text { SIS (USA) } \\
\text { PИНЦ (Russia) } \\
\text { ESJI (KZ) } \\
\text { SJIF (Morocco) }\end{array}$ & $\begin{array}{l}=0.912 \\
=0.234 \\
=\mathbf{3 . 8 6 0} \\
=\mathbf{2 . 0 3 1}\end{array}$ & $\begin{array}{l}\text { ICV (Poland) } \\
\text { PIF (India) } \\
\text { IBI (India) }\end{array}$ & $\begin{array}{l}=6.630 \\
=1.940 \\
=4.260\end{array}$ \\
\hline
\end{tabular}

According to the IAEA Milestone Approach designed for the successful introduction of nuclear power, a country's nuclear programme is said to have attained Milestone 1 when phase 1 of the development of infrastructure is completed. Phase one which is also known as the pre-project phase is the period during which the country looks into what nuclear power entails. At the end of it, the country becomes ready to make commitment based on knowledge [IAEA, 2009b]. During phase 2, preparatory works such as developing the necessary infrastructures are put in place. At the end of this phase, Milestone 2 is said to have been reached. The country will now be ready to invite bids. Just as the United Arab Emirates that selected a bid at the end of 2009 from a consortium led by the Korea Electric
Power Corporation. Turkey cancelled its bidding process in the same year [IAEA, 2009a]. Milestone 3 is attained at the end of phase three. Phase three entails construction activities. When milestone three is reached, the country is then ready to commission and operate its nuclear power plant [IAEA, 2009b]. Nigeria's nuclear power programme is currently at the level of Milestone 2 as shown in Figure 2.

\subsection{Execution of the Nigerian Nuclear Power} Programme

In accordance to the roadmap outlined by the NAEC, a committee was set up for the survey, evaluation and selection of possible sites for a nuclear power plant (NPP). The criterion used for the evaluation of sites is outlined in figure 3 below.

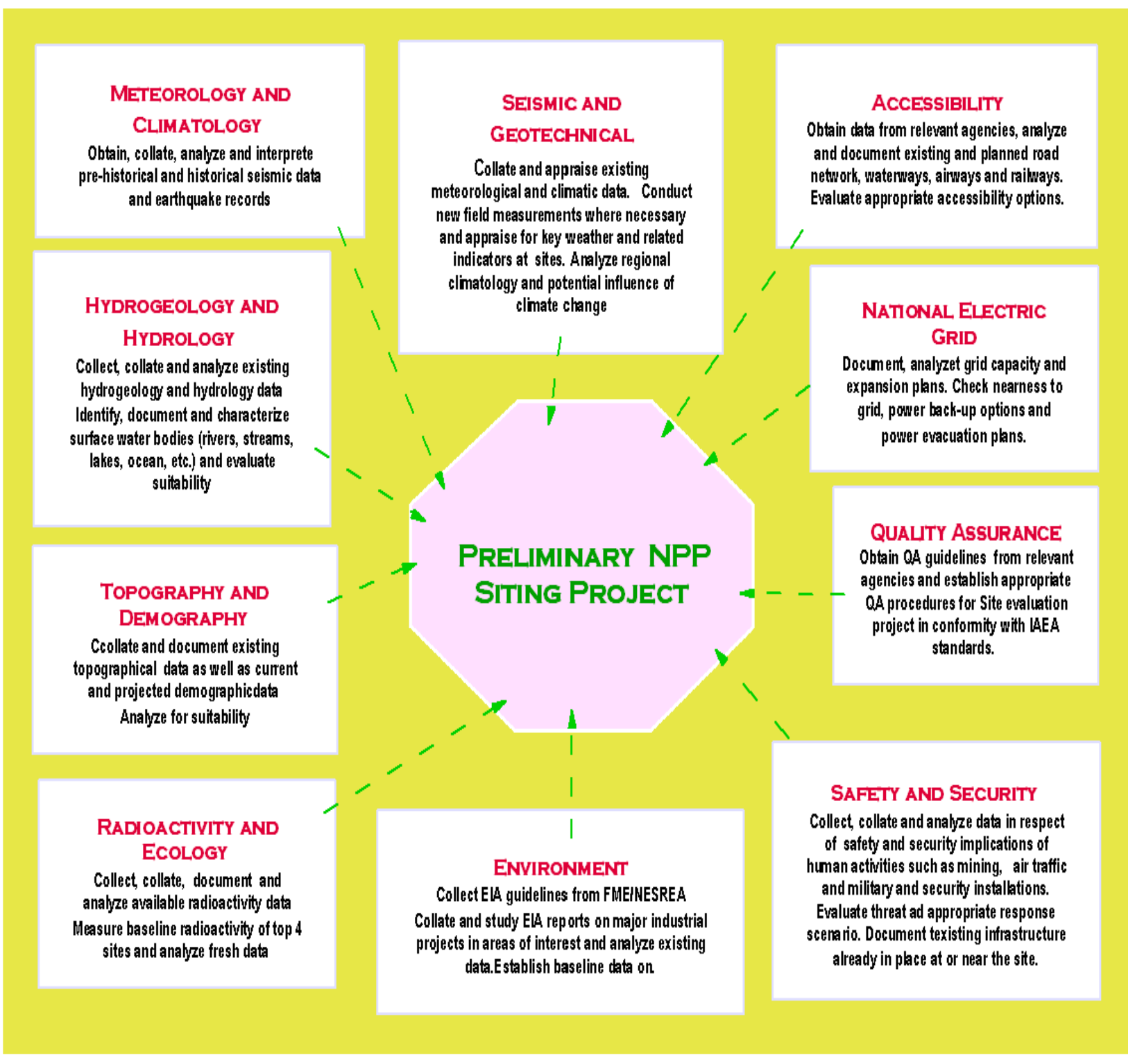

Figure 3 - Considerations in Preliminary Site Selection Activities.

ISPC Industry and technology, 


\begin{tabular}{|c|c|c|c|c|c|c|}
\hline Impact Factor: & $\begin{array}{l}\text { ISRA (India) } \\
\text { ISI (Dubai, UAF } \\
\text { GIF (Australia) } \\
\text { JIF }\end{array}$ & $\begin{array}{l}=1.344 \\
=0.829 \\
=0.564 \\
=1.500\end{array}$ & $\begin{array}{l}\text { SIS (USA) } \\
\text { PИНЦ (Russia) } \\
\text { ESJI (KZ) } \\
\text { SJIF (Morocco) }\end{array}$ & $\begin{array}{l}=0.912 \\
=0.234 \\
=3.860 \\
=\mathbf{2 . 0 3 1}\end{array}$ & $\begin{array}{l}\text { ICV (Poland) } \\
\text { PIF (India) } \\
\text { IBI (India) }\end{array}$ & $\begin{array}{l}=6.630 \\
=1.940 \\
=4.260\end{array}$ \\
\hline
\end{tabular}
selected:

Using the above criteria, four sites were then

1. Geregu/Ajaokuta in Kogi State,

2. Lau Local Government Area in Taraba State,

3. Itu in Akwa Ibom State and

4. Agbaje in Okitipupa Local Government Area
These sites were then submitted to the Nigerian government with two being finally selected as sites for NPPs having a combined capacity of $4,800 \mathrm{MW}$. The two sites selected are Itu in Akwa Ibom state and Geregu in Kogi state as shown in Figure 4. in Ondo State.

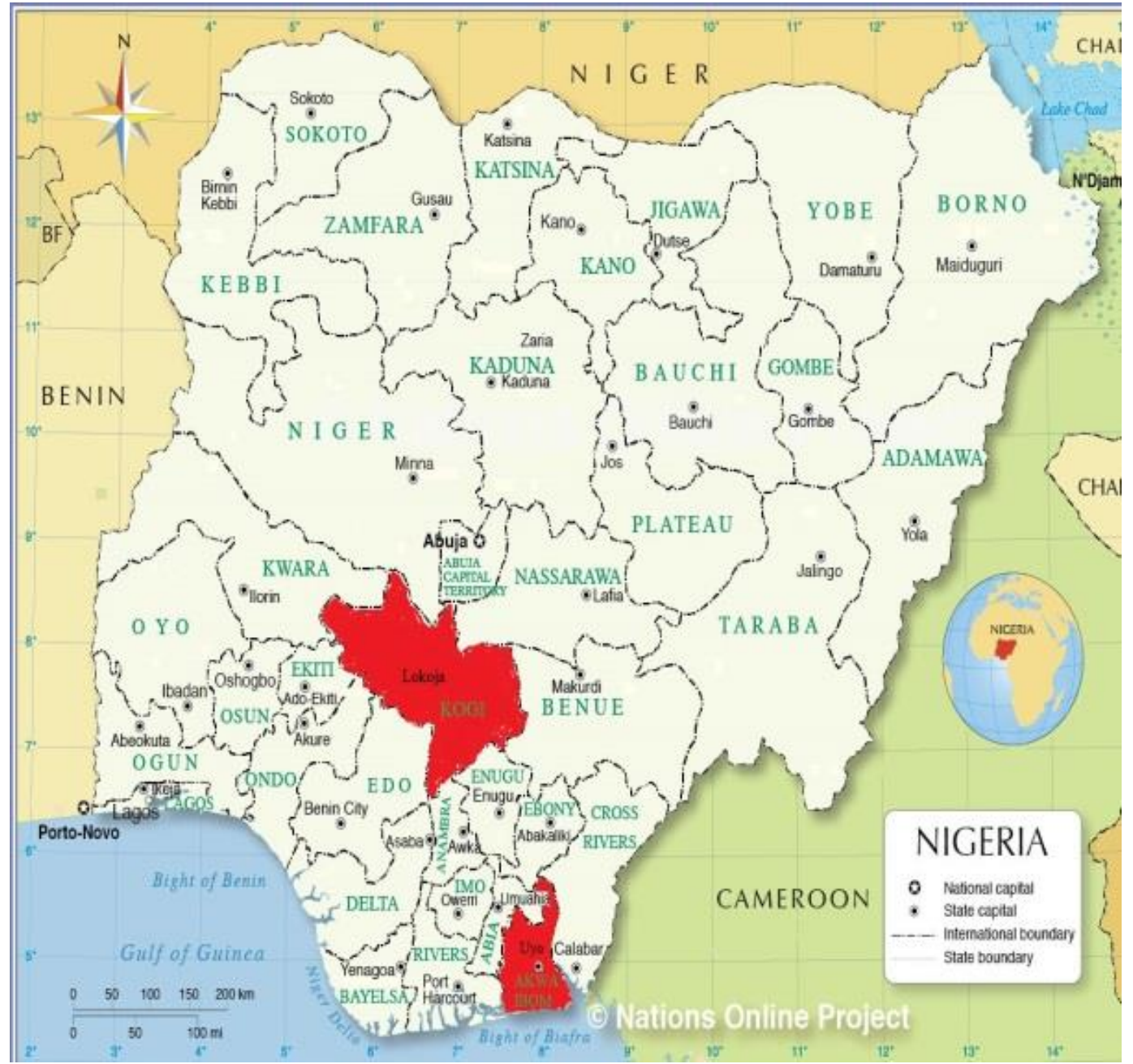

Figure 4 - Map of Nigeria with Selected States Highlighted in Red.

Both sites were announced at a plenary session of the phase 2Integrated Nuclear Infrastructure Review (INIR) in June 2015 with an establishment of the target of $1,200 \mathrm{MW}$ by 2025 and $4,800 \mathrm{MW}$ by 2035. Preliminary licensing of each site by the NNRA is expected by the end of 2016.These nuclear plants will be constructed by Russia's Rosatom Corporation, with financing been handled by both the Nigerian government and Rosatom. The selection of these sites, further development of a National Nuclear Insurance Policy and Scheme in order to adequately address the civil liability of component for the nuclear power industry in conformity with the 1963 Vienna Convention on Civil Liability for Nuclear Damage all point towards the progress made by the Nigerian government towards the achievement of its nuclear policy. The outline of the Nigerian Nuclear programme is shown in Figure 5. 


\begin{tabular}{l|lrl|l|ll} 
& ISRA (India) & $=\mathbf{1 . 3 4 4}$ & SIS (USA) & $=\mathbf{0 . 9 1 2}$ & ICV (Poland) & $=\mathbf{6 . 6 3 0}$ \\
Impact Factor: & ISI (Dubai, UAE) $=\mathbf{0 . 8 2 9}$ & PUHL (Russia) $=\mathbf{0 . 2 3 4}$ & PIF (India) & $=\mathbf{1 . 9 4 0}$ \\
& GIF (Australia) & $\mathbf{0 . 5 6 4}$ & ESJI (KZ) & $=3.860$ & IBI (India) & $=\mathbf{4 . 2 6 0}$ \\
& JIF & $\mathbf{1 . 5 0 0}$ & SJIF (Morocco) & $=\mathbf{2 . 0 3 1}$ & & \\
\hline
\end{tabular}

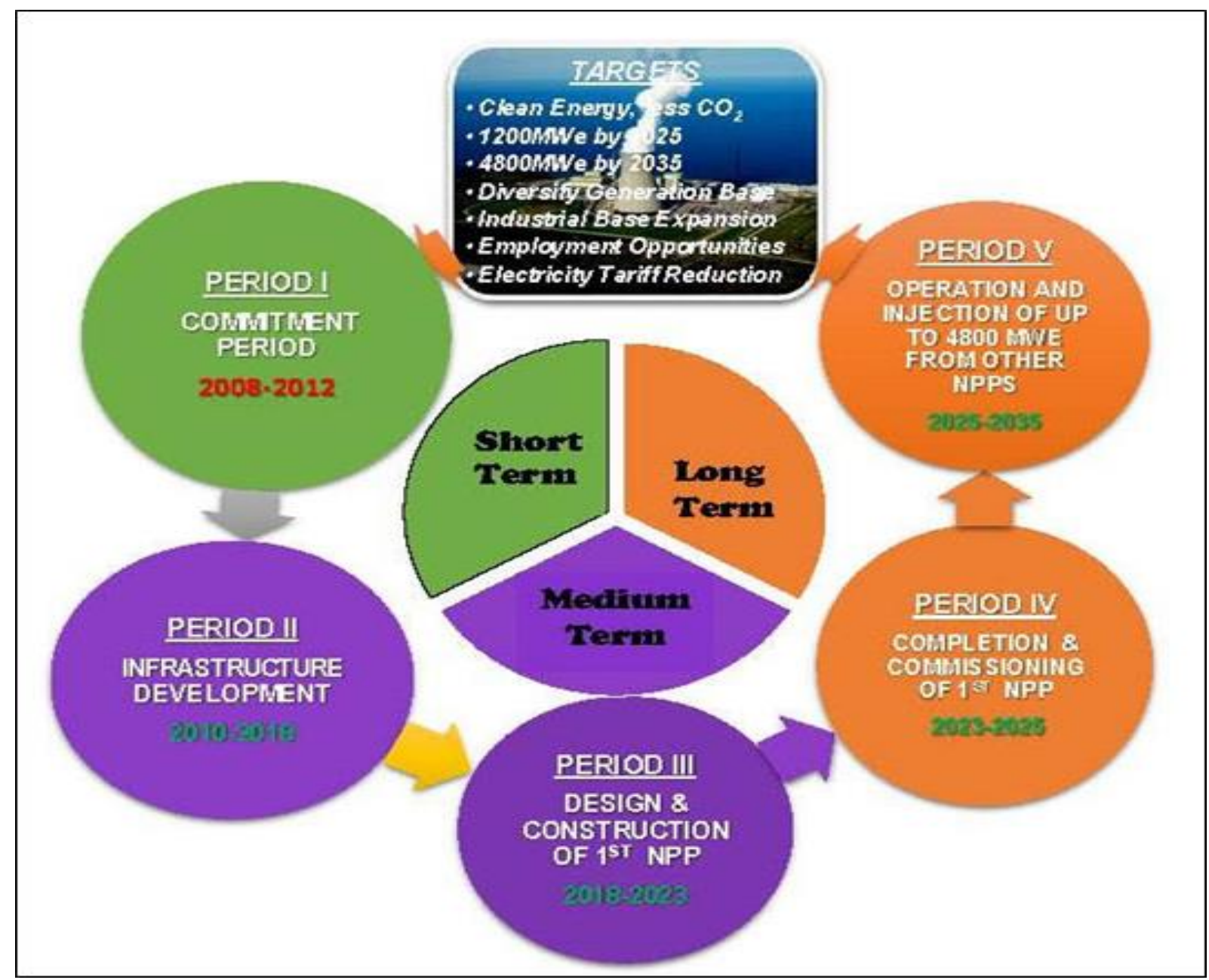

Figure 5 - Outline of the Nigerian Nuclear Programme.

Nigeria has made a number of international agreements with various countries in order to facilitate a smooth execution of its nuclear programme, speed up international nuclear cooperation and develop its nuclear capacity. These include:

1. Nigeria signed a Memorandum of Cooperation with Iran in 2008,

2. Two international agreements to assist in the development of nuclear technology and exploitation of uranium resources were signed with Russia in 2009 [Emma, 2011].

3. Co-operation agreements were also signed with India and South Korea in 2009.

4. Nigeria was one of the first countries to sign and ratify the 1968 Nuclear Non-Proliferation treaty (NPT).

5. A Comprehensive Safeguards Agreement and Additional Protocol with the IAEA, allowing the agency access to a nation's facilities to ensure that peaceful nuclear technology and materials are not diverted to weapon development has been concluded [IAEA, 2009b].

A number of documents have also been signed but not yet ratified. These include:

1. The 1997 Joint Convention on Safety of Fuel Management and Safety of Radioactive Waste Management,

2. The Convention on the Physical Protection of Nuclear Materials and

3. The 1963 Vienna Convention on Civil liability for Nuclear Damage.

4. Risks and Challenges of the Nigerian Nuclear Programme

One of the issues the Nigeria nuclear programme is currently facing and that might prove to be a bigger stumbling block on the road to electricity generation by nuclear power is the public reaction to the programme. Even with less than half of the Nigerian populace being aware of the fact that the country has gotten to phase two of the nuclear programme, it is apparent that over half of that 
number are against the continuation of the programme. State leaders in Akwa Ibom, which is one of the two locations selected for the citing of an NPP have rejected the siting plans. Their actions were attributed to the disasters caused by reactors failures in other countries, the perennial incompetence often associated with matters of safety and security in Nigeria and the population density of the state which is about 706 people per kilometer with a total land area of $7,081 \mathrm{~km}$ square.

Other issues raised include the incompetency of the NEMA and the inexperience of the Rosatom Corporation.

Another challenge that affect the construction of a NPP in Nigeria include the current state of insecurity in the nation, with Boko Haram terrorists raging in the north and Niger Delta militants in the parts of the south-south and south-east of the nation. This has led to questioning of the ability of the government to adequately secure the NPPs after construction.

The process of assigning projects to different parts of Nigeria due to geo-political zoning also raises questions on whether these sites were actually selected on the merit of their topography and ease of evacuation in case of emergency or were just selected by political ideologies. The ability of the National Emergency Management Agency (NEMA) is also called into question. Having failed to properly manage other minor disasters in the past, their ability to properly handle the evacuation and rehabilitation process in case of a nuclear meltdown is doubted.

Another issue is the Nigeria corruption pandemic which has often hampered the development of all major projects embarked on by the federal government for ages. The cutting of corners by contractors and politicians alike in order to achieve personal gain will be to the detriment of a successful nuclear program where even small mistakes in construction might lead to major disasters.

The disposal of radioactive waste, especially high level wastes (HLW) and intermediate level wastes (ILW) is another issue that has been shrouded in uncertainty and that might cause delays in the nuclear programme. The understanding of the impact of the ILW/ HLW management on public acceptance of nuclear technology is something that has not been made apparent by the government and the NAEC. This can be said to be apparent in the mismanagement of the toxic waste dumping case at Koko, Delta state in 1988, when an Italian company shipped in 1, 079, 000 metric tonnes of toxic waste. After the residents of the town resisted the plans to relocate them elsewhere so as to avoid the long-term effects, the toxic waste might have on them, the plans to build a laboratory in order to monitor the effects of the radioactivity on their health all collapsed. This brings to the fore the question of a proper management of nuclear waste that will be generated come 2025 when the first nuclear plant will be connected to the national power grid.

\section{Conclusion}

The success of any project whether big or small is ensured by the endorsement of the people who will be affected either directly or indirectly by its siting, construction and usage. This is very true for a project as massive as the nuclear power programme being embarked upon by the Nigerian government. Especially in view of the fact that nuclear power is the only environment friendly and economically viable project that can provide the Nigerian populace with a much needed stable power supply. Nigeria needs to produce enough power in order to be able to sustain her waning economy and attract back foreign investors who have all abandoned the country due to the high costs of alternative sources of power and thus exponentially increase her industry. It is thus advisable that so as not to have a public outcry of such a magnitude that can throw a wrench in the nuclear programme, the NAEC and other agencies involved should embark on a nationwide sensitization of the public of the readiness and preparedness of the nation to embark on the programme. This is to be achieved by making the general public aware of the environmental and economic benefits of nuclear power compared to others, safety and security issues inherent in deploying nuclear power for power generation, and the various ways it intends to manage the risks involved and the waste produced. Poland, for example had its nuclear programme revived after being stopped when both the government and public opinion changed. Chile is also caarrying its general public along as they consider the nuclear power option, with the Minister of Energy laying much emphasis on public information. Series of public seminars on nuclear power were also conducted with opinion leaders and the general public in attendance. Also, it is important to note that the IAEA has the authority to approve, regulate and monitor civil nuclear uses worldwide and that the agency will never have approved the Nigeria nuclear programme if there were discrepancies or inadequacies in the country's ability to successfully construct and operate a nuclear power plant. More legislation that will serve as a check to corrupt practices in the nuclear programme should also be made so as to prevent the perversion of the project. The security of the nuclear power plants should also be made a top priority to the Nigerian security agencies in order to prevent the attacks on the reactors by criminal deterrents. Residents of the localities in which the 


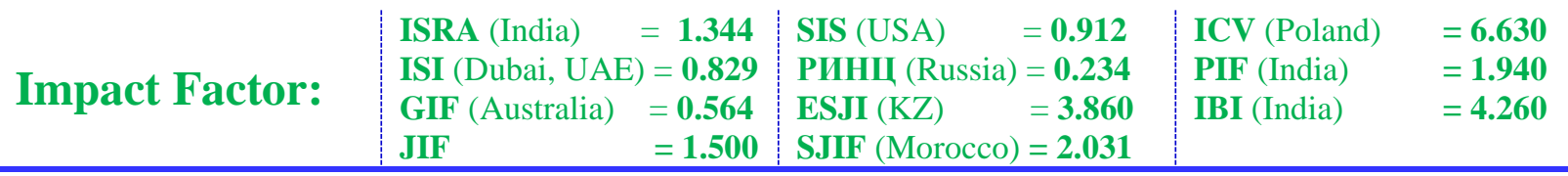

plants are to be sited should also be sensitized periodically of the evacuation plans in case of a meltdown so as to prevent loss of lives. The educational, financial and industrial sectors should also be engaged so as to take advantage of the project and the opportunities that will create by the implementation of the project.

\section{References:}

1. Emma A (2011) "24 Years After the Drums of Death: A New Air in Koko", Available: www.vanguardngr.com/2011/07/24-years-after"the-drums-of-death-a-new-air-in-koko/, (Accessed: July 31, 2011).

2. Esogbue AO, Osaisai FE (2011) "Networking of National Universities for the Implementation of a Graduate Program in Nuclear Science and Engineering: The Advantages and Challenges", Paper Presented at the National Workshop/Expert Mission on Education and Training for the Implementation of the Nuclear Energy Programme in Nigeria. December 13 14, 2011. Abuja, Nigeria.

3. Francis I (2014) “An Overview of Nigeria's Nuclear Energy Programme in the INPRO Methodology area of Infrastructure", Centre for Energy Research and Development, Obafemi Awolowo University, Ile-Ife. Nigeria, 8th INPRO Dialogue Forum, Vienna, 26-29 August, 2014.

4. IAEA (2009) "Status and Trend of Nuclear Technologies", Report of the International Project on Innovative Nuclear Reactors and Fuel Cycles (INPRO) IAEA-TECDOC-1622, 2009a.

5. IAEA (2009) "Initiating Nuclear Power Programmes: Responsibilities and Capabilities of Owners and Operators", IAEA Nuclear Energy Series, No. NG-T-3.1, 2009 b.
6. NAEC (2011) Website. Available: http://www.nigatom.org.ng (Accessed: 10.04.2017).

7. Osaisai FE (2011) "Nuclear Power Introduction in Nigeria: Organization and Way Forward", Paper presented at the Second Regional Conference on Energy and Nuclear Power in Africa, Cape Town, South Africa, 2011a.

8. Osaisai FE (2011) "Status and Plans for NPP Infrastructure Development in Nigeria", Paper Presented at the National Workshop/Expert Mission on Human Resources Development for Nigeria's Nuclear Power Programme; Strategies for Implementation, Abuja, Nigeria, 2011b.

9. Simon Echewofun Sunday (2015) "FG picks Geregu, Itu as 2, 400MW nuclear power sites", Available:

www.dailtytrust.com.ng/daily/index.php/busine ss/57411-fg-picks-geregu-itu-as-2-400mwnuclear-power-sites (Accessed: June 17, 2015).

10. Yehuwdah EC, Bamidele F Ebiwonjumi (2013) "Nigeria's Nuclear Power Generation Project: Current State and Future Prospects", Journal of Energy Technologies and Policy, www.iiste.org, Vol.3, No.7, p.63-75.

11. Yusuf OA (2016) "Radioactive waste Disposal: Hindrance to Nigeria's Civil Nuclear programme", Available: www.opinion.premiumtimesng.com/2016/05/23 /172942/ (Accessed: 10.04.2017). 